\title{
Metaphor Used in The News Items of Economy and Business Segments in The Jakarta Globe News Portal
}

\section{Komang Sri Swandewi*, I Nyoman Adi Jaya Putra², Dewa Ayu Eka Agustini3}

1,2,3 English Language Education, Universitas Pendidikan Ganesha, Singaraja, Indonesia

\section{A R T I C L E I N F O \\ Article history: \\ Received July 22, 2021 \\ Revised July 29, 2021 \\ Accepted September 14, 2021 \\ Available online October 25, 2021 \\ Kata Kunci: \\ Metafora, Prosedur Identifikasi Metafora (MIP) \\ Keywords: \\ Metaphor, Metaphor Identification Procedure (MIP)

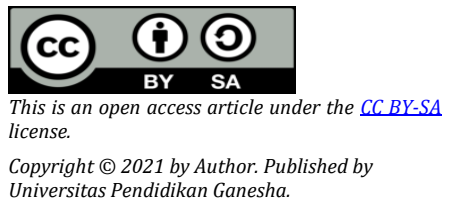 \\ Copyright $(2021$ by Author. Published by Universitas Pendidikan Ganesh}

\begin{abstract}
A B S T R A K
Penelitian ini bertujuan untuk menganalisis jenis metafora yang digunakan dalam segmen berita ekonomi dan bisnis di Portal Berita Jakarta Globe dan mengidentifikasi jenis metafora yang paling banyak digunakan di antara segmen berita ekonomi dan bisnis di Portal Berita Jakarta Globe. Desain penelitian ini adalah analisis wacana dengan pendekatan kualitatif. Objek penelitian ini adalah metafora. Subyek penelitian ini adalah segmen berita ekonomi dan bisnis di Portal Berita Jakarta Globe. Dalam mengidentifikasi metafora tertentu, metode yang digunakan adalah MIP (Metaphor Identification Procedure). Pengumpulan data dilakukan dengan menggunakan pengumpulan dokumen. Instrumen proses pengumpulan data yang digunakan peneliti, catatan, dan daftar periksa. Data dianalisis secara deskriptif dengan menggunakan model Miles dan Huberman. Temuan penelitian ini menunjukkan bahwa ada empat jenis metafora yang digunakan dalam segmen berita ekonomi dan bisnis di Portal Berita Jakarta Globe. Mereka adalah metafora struktural, orientasional, ontologis, dan antropomorfik. Metafora struktural muncul sebagai yang paling banyak digunakan dalam segmen berita ekonomi dan bisnis Portal Berita Jakarta Globe dengan total 61 metafora atau $78,20 \%$ dari metafora yang dianalisis.
\end{abstract}

\section{A B S T RACT}

This study aims to analyze the kinds of metaphors used in the economy and business news segment of the Jakarta Globe News Portal and identify which kinds of metaphors that is most widely used among the economy and business news segment in the Jakarta Globe News Portal. The design of this study was discourse analysis with qualitative approach. The object of this study was metaphor. The subjects of the study were the economy and business news segment in the Jakarta Globe News Portal. In identifying a particular metaphor, the method used was MIP (Metaphor Identification Procedure). The data were collected by using documents collection. The instruments of data collection process were used researcher, notes, and checklist. The data were analysed descriptively by using Miles and Huberman model. The findings of this study showed that there were four kinds of metaphor used in the economy and business news segment of the Jakarta Globe News Portal. They were structural, orientational, ontological, and anthropomorphic metaphor. Structural metaphor appeared as the most used in the economy and business news segment of the Jakarta Globe News Portal with the total of 61 metaphors or 78.20\% of the metaphors analysed.

\section{INTRODUCTION}

Reading is one of inseparable activity in humans' daily life. Reading is defined as the most powerful ways that provide numerous information for having knowledge about all the entities in life (Herlina, 2016; Surdyanto \& Kurniawan, 2020). The current situation shows that a flood of information occurs in society in which the readers have been drowned to the jungle of language by the abundant sources. This conditions emerges passive readers who accept all the information from the outside without filtering the information that they read (Surdyanto \& Kurniawan, 2020). It shows that reading is a beneficial activity that improves people's knowledge and understanding toward the world. Nowadays, people tend to choose read a news as a simple way to do something in their daily lives. News is defined as a discourse where people can discuss its communicative context if the specific audiences and a particular objective addressed in that news (Puspita \& Pranoto, 2021). Newspaper is a common means used by people to read news. Newspaper is a pleasuring source for the readers in which it is considered as the prototype basic of modern socialization tools (Khorsheed \& Rassoul, 2018). Reading newspapers is beneficial for young citizens for developing their language ability and having knowledge related to current situation in which newspapers indicate the policies, the corporate sector, and the government by providing a criticism of economic social - political issue and other information (Baruah \& Paulus, 2019).

The rapid growth of mass media is a compatible situation relevant to the increasing necessity of information considering that mass media is widely used as a means for sharing and delivering messages 
from a communicator the public. Each mass media adopts an ideology due to the originality of their publishing news in maintaining public trustworthiness toward the media (Evianda et al., 2019). The development of growth media is related to the innovation needed by people toward their reading activities considering that people will look for ways to make more efficient use of their time in reading news. A new innovation is needed by people, where newspapers are no longer needed and turn to something more efficient than newspapers. This will make it easier for people to read the news anywhere and anytime, moreover through Smartphone. It is currently widely used can access the latest news from various countries. People do not need to buy a newspaper anymore if they want to read just one section such as the economic section, sport section, and that will make other parts useless. This phenomenon is supported by previous study who state that people tend to rely on the use of internet in finding the primary source of information particularly news (Sakarkar \& Rangari, 2019). Therefore, most of broadcasting companies provide and update new information immediately through their websites.

Since, reading news has been one of routines of most people in the world, including students. However, problems arise when they deal with some words and phrases which contains of figurative language such as personification, hyperbole, metaphor, metonymy, etc. Figurative language is a user of language to make the expression of language more beautiful and effective (Regmi, 2015). Figurative language often provides a more effective means of saying what people mean than a direct statement. In addition, figurative language is generally defined as any way of gives something different to says than the ordinary way (Ayu \& Maili, 2016). Figurative language is a language commonly used in the form of words or expressions which has a different meaning from its literal interpretation. It shows the creativity or the aesthetic literary of the speakers or authors in which it is generally found in the articles, newspapers, advertisement, poems, novels, or even in daily conversation (Harya, 2017; Musfira, 2021). It is more specific definable as a way of saying one thing and meaning another in the word. The effective use of figures of speech brings to the life of language what would have been mere words, phrases, and sentences. Then, the use of figurative language can show the author's intent and take the reader on a journey through what he or she experienced at specific periods in time. It brings beauty, emphasis, and clarity to language.

On another side, figurative language is viewed as a challenging topic in EFL context considering its unusual meaning and symbols (Salwa \& Liskinasih, 2016). There are several elements of figurative language widely discussed and observed in EFL classrooms. Metaphor is one of the language features quite widely used by journalist of papers. Students' comprehensions when reading news in some cases are always hampered due to the use of metaphor. It occurs with some of reasons, those are English metaphor receive less attention in news and lack of knowledge about metaphor. Metaphor is used for expressing a unique object and an attractive or creative meaning in which it is lexicalized in the form of words (Hadiyansyah \& Hidayat, 2019). The standard approach used in interpreting metaphor is the similarity of the person or the thing compared to another thing that is contrast and has a different form from them (Abuzahra \& Salahat, 2018). The earliest theory shows that metaphor is a figure of speech in which an implied comparison between different things that actually have something in common and applicable (Pitcher, 2013). Moreover, metaphor is typically viewed as characteristic of language alone, a matter of words rather than thought or action. However, as time changes people have found that metaphor is pervasive in everyday life, not just in language but in thought and action. A metaphor is an imaginative way that people want to express especially in news. The use of metaphor is quite common in the news article. Moreover, using metaphor will cause a sort of specific feature of the paper itself.

Jakarta Globe is one example of news portal written in English language. The writers of articles in news portal tend to use metaphor in writing the headlines or inside news text. The use of metaphorical expressions by journalists sometimes leads up to give hidden message or information. Jakarta Globe has some information about problematic situations with the new through article every day such as domestic and international political issues, economic and business issues, lifestyle, etc. Inside economic and business segment can find metaphor that journalist uses, but the use of metaphor difficulty to understand the article in the segment. Those drive this research to be conducted. The idea then came to make the researcher interested in conducting research about the analyses of the use of metaphor in the news portal, which is the economy and business news segment in Jakarta Globe news portal. The example of metaphor in economic and business news segment were taken from Jakarta Globe news portal on December, 2020 edition. To understand some information related the news portal, the researcher has explored the economy and business news segment in Jakarta Globe news portal before which is allowing researcher to do several primary observations directly. Then, the writer is more to choose one segment that is the economy and business in the Jakarta Globe news portal as material for this research because the information is needed by everyone and also economic and business is playing an important role for every country's future.

Enormous theories and empirics around metaphor in the news has been produced and conducted (Kesumayanti et al., 2013); Brahwija, 2018). Most of them investigate about metaphor in the news such as 
in the newspaper and news portal. Compared to the topic of metaphor in the newspaper in general, the discussion around the use of metaphor in the news portal inclines to be getting little attention. Though, it portrays that the topic about metaphor in the news portal needs to get more update because some people incline more reads the news through the internet. Therefore, this research will focus on metaphor as the phenomenon of language on the news items in the news portal. The economic and business segment in the news is determined in this research because it was more interest in which Indonesian people highly paid attention about the segment of the news. This research further offers the information around the topic of the use of metaphor in Economy and Business news segment in Jakarta Globe news portal.

\section{METHOD}

This research uses qualitative descriptive method. This study focuses on the analysis of metaphor in the economy and business news segment of Jakarta Globe News Portal. This study was conducted with the aim to identify the kinds of metaphors are used and the kinds of metaphor that are mostly used in the economy and business news segment of Jakarta Globe News Portal. The subject of this study is news items of economic and business segments in the Jakarta Globe News Portal. The author selecting the economy and business news segment in the Jakarta Globe News Portal because has many figures of speech and used English daily. The object studied in this study is metaphor, the kind of metaphor used in the news item and the kinds of metaphor that mostly used in the economy and business news segment in Jakarta Globe News Portal. The instruments of data collection of this research are researcher, notes and checklist. The researcher will be the main instrument who acts as a data collector, data interpreter, analysts, and also summarizer of the research results. The researcher's thought and decision will influence the final research findings. Then, notes also the instrument that is uses in this study. It used to write down the metaphorical expressions during the process of identification by using MIP. The notes were related to seek the meanings of the metaphorical expressions which can be seen in table. Checklists were used to categorize the metaphorical expressions used in the economy and business news segment of Jakarta Globe News Portal based on the kind of metaphor. The checklist was made based on the kind of metaphor synthesized from the classification of some experts. There are six kinds of metaphors that used are structural metaphor, orientational metaphor, ontological metaphor, anthropomorphic metaphor, animal metaphor, and synaesthesia metaphor.

This study the data was obtained through document collection. Document collection is a noninteractive strategy in collecting qualitative data (McMillan \& Schumacher, 2010). Documents are divided into official documents, personal documents, group documents, and objects. The news items of economy and business segments in the Jakarta Globe News Portal can be classified as official documents. In this study is used qualitative descriptive analysis. Data analysis is done since before entering the field, during in the field, and after finished in the field. Once the data is collected as a whole, and the data are classified, described and analysed based on this research problem. In detail the data analysis technique is selecting particular news in the economy and business segment in Jakarta Globe News Portal purposively, collecting expressions used in the news items suspected as metaphorical expressions in particular news on the economy and business segment in Jakarta Globe News Portal and repeating steps 1 and 2 until there was a saturated point of the data.

The data analysis process in this qualitative research was conducted during data collection process rather than after the data collection process. In this study, the activities of data analysis based were conducted through three steps: data reduction, data display, and conclusion drawing and verification. In this study the researchers selecting particular news in the economy and business segment in Jakarta Globe News Portal. Furthermore, the researcher read news item of the economy and business can be analysed and dispose of data that are considered unimportant. Data reduction is done through activities in the form of identification and classification. Data that has been reduced will be presented next data description which will be described in detail and clear. In the data display, the data obtained will be associated with relevant theories that will be able to answer the problems to be solved. In this study the descriptions are done on each data in accordance with the presentation of data in the form of table or chart. The Conclusion drawing and verification is a process of making draw of conclusion based on the prefigured data that have been done from the beginning and must be able to answer the issues that will be raised in the research. So that the final result will be obtained information about the kinds of metaphor are used and the kinds of metaphors most widely in the economy and business news segment in Jakarta Globe News Portal.

\section{RESULT AND DISCUSSION}




\section{Result}

The data were obtained data from the most viewer on the Jakarta Globe News Portal in December 2020. The economy and business were the favourite segments in this news portal. It covered news concerning economy and business around Indonesia. The total amount of metaphor found in this segment was 78 metaphors. Then, the data were identified using MIP (Metaphor Identification Procedure). The checklist was used to obtain the kinds of metaphors used in the economy and business segment in Jakarta Globe news portal. It showed that the economy and business segment had used four kinds of metaphors. They were structural metaphor, orientational metaphor, ontological metaphor, and anthropomorphic metaphor. There was no animal metaphor and synesthesia metaphor. Then, structural metaphor becomes the most kinds of metaphor commonly used in the economy and business news segment, followed by ontological metaphor in the second place, orientational metaphor in the third place, and anthropomorphic metaphor in the last place. The frequency of kinds of metaphor can be seen in Table 1.

Table1. The frequency of the kinds of metaphor in the economy and business news segment

\begin{tabular}{cccc}
\hline No & Kinds of Metaphor & Number of Metaphor & $\begin{array}{c}\text { Percentage of Total } \\
\text { Number (\%) }\end{array}$ \\
\hline 1 & Structural Metaphor & 61 & 78.20 \\
2 & Orientational Metaphor & 7 & 8.97 \\
3 & Ontological Metaphor & 8 & 10.25 \\
4 & Anthropomorphic Metaphor & 2 & 2.56 \\
5 & Animal Metaphor & 0 & 0 \\
6 & Synaesthesia Metaphor & 0 & 0 \\
\hline & Total & $\mathbf{7 8}$ & $\mathbf{1 0 0}$ \\
\hline
\end{tabular}

The total number of structural metaphors was 61 or $78.20 \%$ in the economy and business news segment of Jakarta Globe News Portal in December 2020. In second position, it was ontological metaphor with total number of 8 or $10.25 \%$ metaphor. Then, the third position was orientational metaphor with 7 total numbers or $8.97 \%$. The last was anthropomorphic metaphor with total number of 2 and its existence was $2.56 \%$. It can be concluded that structural metaphors were the most kind of metaphor used in the economy and business news segment of Jakarta Globe News Portal.

\section{Discussion}

From the result, it can be seen that some sentences on news text in the economy and business segment in the Jakarta Globe News Portal uses some kind of metaphors in delivering their news. Although metaphor is commonly used in literature such as novels, short stories, etc, it is also used in news item. It is in line with a study which kind of metaphors were in the tempo.co news portal in March 2017 (Brahwija, 2018). The use of metaphor supports the expression and vividness in conveying the intended meaning of the news item. It proves that metaphor is connected to characteristics of journalistic language such as simple sentence in delivering news content and being brief. The present study covers two main points in the discussion. First, it covers the kinds of metaphor that is used in the economy and business news segment in Jakarta Globe news portal, namely structural metaphor, orientational metaphor, ontological metaphor, and anthropomorphic metaphor. Second, it discusses the most metaphor used in the economy and business news segment that is structural metaphor. In the present study, the checklist method used to search for the kinds of metaphor applied theory (Lakoff and Johnson, 1980; Parera, 2004; Rahman, 2018). At the first part, several types of metaphor used in the economy and business segment include structural metaphor, orientational metaphor, ontological metaphor, and anthropomorphic metaphor. The similar studies about the types of metaphor have been conducted about Corona issues (Ahmad et al., 2019) and about political (Aqromi, 2020). On the other hand, those previous studies only find out three types of metaphor presented in health and politic issues which are different from the present study, namely oriental metaphors, ontological metaphors, and structural metaphors. It can be said that health and political aspect do not refer to body human. Some other researchers also conduct the study relating to the news which discuss different metaphor in their studies. Another study discusses the function of pragmatic in using metaphor. It has antagonistic, persuasive, and emotive characteristic (Sopuluchi et al., 2020). There is a message behind sport entertainment that brings implication to scholarship and social behaviour. On the other side, the lexical pattern provides a relationship between affiliation and readers (Liu, 2018). The translation procedures which are used to translate the metaphors covering translation of the similar image, replacement of image, using simile, making sense of metaphor, and deletion of metaphors (Jayawardani et 
al., 2020). Different from another study who describes the cognitive metaphor or conceptual metaphor of Covid-19 in different situation of communication (Kozlova, 2021).

After analysing the kinds of metaphors, the researcher analyses the kinds of metaphor that mostly used in the economy and business news segment in Jakarta Globe news portal. Structural metaphor as mostly used in the economy and business news segment, with followed by ontological metaphor in second place, orientational metaphor in third place, and anthropomorphic metaphor as the last used metaphor. Considering the dominant type, it proves the fact from Lakoff and Johnsonn (1980) that structural metaphor is the biggest kind of metaphor compared to the other kinds. It can be seen from many sentences in news in the economy and business segment written by journalists by replacing the general term with other terms without changing or not changing the meaning of the object. It is because of its simplicity and noncomplicated use, sometimes some meanings in structural metaphor are less figurative and more literal in meaning (Lakoff \& Johnson, 1980). The previous research found that structural metaphor as the most kinds of metaphor that used in the news. Brahwija (2018) also finds out that structural metaphor becomes the dominant types used in the news portal. His study covers several news segments with total number of 220 or almost $50 \%$ from other metaphor. In his study, the structural metaphor is about sport segment, science and technology segment.

The dominant types of metaphor in this study are line with a study found that structural metaphor becomes the most dominant kinds of metaphor (Chaerunnisah, 2020). The structural metaphor is used to describe concrete object. The second most common kind of metaphor seen in the economy and business news segment is ontological metaphor. Ontological metaphor refers to the target domain is vague or abstract but its existence can be conceived (Lakoff \& Johnson, 1980). It based on people's experience with physical objects in their daily life. Ontological metaphor becomes the second dominant kinds of metaphor in the economy and business segment which has the percentage of $10.25 \%$ with the number of metaphors around 8 . The previous research found that ontological metaphor as the second most kinds of metaphor that used in news item is (Brahwija, 2018). In his study, ontological metaphor becomes the second dominant kinds of metaphor that have total number of metaphors around 49 and its existence is around $14 \%$. It can be concluded that both studies have the same ontological metaphor as dominant types of metaphor used in news item. In the third position, it covers orientational metaphor. Orientational metaphor involves the use of words that are associated with spatial orientation about physical and psychological states such as updown, on-off, (Lakoff \&Johnson, 1980). The percentage of orientational metaphor covers $8.97 \%$ with the number of 7 .

This finding is in line with a study that stated orientational metaphor in the third position with total number of 4 kinds of metaphor or 14, 81\% (Damayanti \& Marzuki, 2019). They analyse metaphor on political issue in the Jakarta Post newspaper. It's show that both studies have the same findings in term of the orientational metaphors used in news item. The last is anthropomorphic metaphor. It associated as a kind of metaphor that uses the anatomical part of the human body as a medium in its use (Rahman, 2019). Anthropomorphic metaphor is the least metaphor found from the Economy and Business news segment in Jakarta Globe News Portal with total number of metaphors only 2 and its presence is around $2.56 \%$ from this segment. It is in line with a study that finds out 2 number of anthropomorphic metaphors from all segments in tempo.co (Brahwija, 2018). However, both studies have different analysis of the news segment. Anthropomorphic metaphor on four news segments, while the present study only analyses the anthropomorphic metaphor on one segment (Brahwija, 2018). It can be said that difficulty finding anthropomorphic metaphor in the news especially from the economy and business news segment in Jakarta Globe News Portal. The expressions of metaphor in news headline are different from any languages. It is based on the physical, cultural, and natural situation of the country. The information of the news can be understood from those factors (Gao, 2016; Stojan \& Mijić, 2019; Adam, 2020). In addition, the use of metaphor is used to encourage the policy maker of the government (Healy \& Williams, 2017).

\section{CONCLUSION}

Based on the finding and discussion, the present study has found that four kinds of metaphors are used in the economy and business news segment in Jakarta Globe news portal. They are structural metaphor, orientational metaphor, ontological metaphor, and anthropomorphic metaphor. The structural metaphor becomes the dominant kinds of metaphor and the anthropomorphic metaphor is least kind metaphor used in the Jakarta Globe News Portal in this study. The present study gives an impact especially for the journalistic writings in which it can elaborate them to create better and creative writing for their news. In addition, there are several suggestions for some parties. For English teacher, this study can help teachers in giving lesson about metaphor to students. The teacher can create a practice for students to get better understanding toward the use of metaphors in making a sentence or communication. For the 
students, it is really important to know and understand the use and kinds of metaphors in the news. They can comprehend the meaning of the news. The last is for other researchers. It can be used as a reference to other researchers who plan to conduct similar study. It is expected to help those who do deeper research on the use of metaphors in different spheres such as different news, segments, etc. It is also suggested that other researchers can find another aspect like the reason behind choosing the expression of metaphor.

\section{REFERENCES}

Abuzahra, N., \& Salahat, R. (2018). Analyzing Iago 's speech in shakespeare 's othello. Indonesian Journal of English Language Teaching and Applied Linguistics Vol., 2(2), 185-203. https: //pdfs.semanticscholar.org/79ca/1d951902872db1ece17094a01a8bf70fc606.pdf.

Adam, M. (2020). Curing the infected wound: metaphor of state-owned enterprises in news headlines. Ethical Lingua: Journal of Language Teaching and Literature, 7(2), 187-199. https://doi.org/10.30605/25409190.183.

Aqromi, N. L. (2020). An Analysis of Metaphor for Corona on Headlines News. Pioneer, 12(2), 157-164. https://ojs.unars.ac.id/index.php/pioneer/article/view/734.

Ayu, D. M. I., \& Maili, S. N. (2016). The analysis figurative meaning of Jakarta Post a paper. Deiksis, 8(8), 102110. https://journal.lppmunindra.ac.id/index.php/Deiksis/article/view/672.

Baruah, J., \& Paulus, P. B. (2019). Collaborative creativity and innovation in education. January, 155-177. https: //doi.org/10.1007/978-3-319-90272-2_9.

Brahwija, I. B. (2018). An analysis of metaphor used in the news item of news segments in tempo.co news portal on march 2017. Journal Pendidikan Bahasa Inggris Undiksha, 1(1), 1-9. https: //ejournal.undiksha.ac.id/index.php/JPBI/article/download/15165/9268.

Chaerunnisah, I. U. (2020). An analysis of metonymy and metaphor in selected news articles related to sports in the jakarta post. PRASASTI: Journal of Linguistics, 5(2), 152-162. https://jurnal.uns.ac.id/pjl/article/view/40094.

Cruz, S. (2015). Images and kant ' s theory of perception. Ergo, 2(29), 737-777. https://quod.lib.umich.edu/cgi/t/text/idx/e/ergo/12405314.0002.029/--images-and-kantstheory-of-perception?rgn=main;view=fulltext.

Damayanti, A. R., \& Marzuki, J. (2019). An analysis of metaphor on poitical issues in the jakarta post newspaper. Jurnal Online Mahasiswa, 3(1), https://media.neliti.com/media/publications/198701-an-analysis-of-metaphor-on-politicaliss.pdf.

Démuth, A. (2012). Perception theories. In Applications of Case Study Research (Issue 4).

Evianda, E., Ramli, R., \& Harun, M. (2019). Critical discourse analysis on women's position in prohaba daily news texts. Studies in English Language and Education, 6(2), 273-285. https://doi.org/10.24815/siele.v6i2.14783.

Gao, L. (2016). A comparative study of conceptual metaphors in english and chinese economic news headlines. Creative Education, 07(17), 2629-2639. https://doi.org/10.4236/ce.2016.717247.

Gellatly, A. (1999). Perception and information processing. Behavioral and Brain Sciences, 22(3), 377-378. https: //doi.org/10.1017/S0140525X9935202X.

Hadiyansyah, D., \& Hidayat, D. N. (2019). Understanding corruptors' imagination concerning money through their metaphors. JEE (Indonesian Journal of English Education), 6(2), 153-170. https://doi.org/10.15408/ijee.v6i2.

Harya, T. D. (2017). An analysis of figurative languages used in coelhos's novel entitled "alchemist." PREMISE JOURNAL, 5(2), 46. https://doi.org/10.24127/pj.v5i2.815.

Healy, G., \& Williams, P. (2017). Metaphor use in the political communication of major resource projects in Australia. Pacific Journalism Review, 23(1), 150-168. https://doi.org/10.24135/pjr.v23i1.103.

Herlina. (2016). The effect of interest in reading on mastery of english vocabulary with fifth grade elementary students. Studies in English Language and Education, 3(2), 192. https://doi.org/10.24815/siele.v3i2.4965.

Jayawardani, T. S. F., Tabiati, S. E., \& Sahiruddin. (2020). Types of metaphors and translation procedures used in indonesian subtitle of 12 years a slave. Metalingua, 18(2), 263-270.

Kesumayanti, M. L., Putra, N. A., \& Wage, P. N. (2013). An analysis of metaphor used in the news items of jakarta post newspaper. Jurnal Pendidikan Bahasa Inggris Undiksha, 1(1), 1-9. http://dx.doi.org/10.23887/jpbi.v1i1.3387.

Khorsheed, R., \& Rassoul, J. (2018). The role of using english newspapers in enhancing pre-intermediate level learners' reading comprehension skills. Theory and Practice in Language Studies, 8(10), 1370. https://doi.org/10.17507/tpls.0810.17. 
Kozlova, T. (2021). Cognitive metaphors of covid-19 pandemic in business news. SHS Web of Conferences, 100, 02004. https://doi.org/10.1051/shsconf/202110002004.

Lakoff, G., \& Johnson, M. (1980). Metaphors we live by. The University of Chigaco Press.

Liu, F. (2018). Lexical metaphor as affiliative bond in newspaper editorials: a systemic functional linguistics perspective. Functional Linguistics, 5(1). https: //doi.org/10.1186/s40554-018-0054-z.

McMillan, J. ., \& Schumacher, S. (2010). Research in education. Pearson.

Miles, M. B., \& Huberman, A. M. (1994). An expanded sourcebook: qualitative data analysis (second edi). Sage Publications; International Educational and Professional Publisher.

Musfira. (2021). Figurative language in the dialogue of mappettu ada ( marriage proposal ) in buginese culture. Elite; English and Literature Journal, 8(1), 64-75. http://journal.uinalauddin.ac.id/index.php/elite/article/view/20523.

Parera, D, J. (2004). Teori Semantik Edisi Kedua. Erlangga.

Pitcher, R. (2013). Using metaphor analysis: mip and beyond. Qualitative Report, 18(34), 1-8. https://nsuworks.nova.edu/cgi/viewcontent.cgi?article=1476\&context=tqr.

Puspita, D., \& Pranoto, B. E. (2021). The attitude of Japanese newspapers in narrating disaster events: appraisal in critical discourse study. Studies in English Language and Education, 8(2), 796-817. https://doi.org/10.24815/siele.v8i2.18368.

Rahman, I. A. (2019). Metaphor analyzes on students' english poems. English Language in Focus (ELIF), 1(1), 1-8. https://jurnal.umj.ac.id/index.php/ELIF/article/view/4489.

Regmi, L. R. (2015). Analysis and use of figures of speech. Journal of NELTA Surkhet, 4(July 2015), 76-80. https://doi.org/10.3126/jns.v4i0.12864

Sakarkar, G., \& Rangari, P. (2019). News portal ( centraltimes . in ). International Journal of Engineering Science and Computing, 9(4). https://www.researchgate.net/profile/GopalSakarkar/publication/332539376_News_Portal_centraltimesin/links/5cbadce9a6fdcc1d49a1136 6/News-Portal-centraltimesin.pdf.

Salwa, S., \& Liskinasih, A. (2016). The use of songs in increasing students' understanding of figurative language. IJEE (Indonesian Journal of English Education), 3(1), 75-88. https://doi.org/10.15408/ijee.v3i1.3443.

Sopuluchi, N. C., Tochukwu, C. J., \& Zubairu, S. B. (2020). Metaphors of war and engagement in selected sports newspaper reports in nigeria. International Journal of Humanities and Social Science Invention, 9(10), 12-17. https: //doi.org/10.35629/7722-0910021217.

Stojan, N., \& Mijić, S. N. (2019). Conceptual metaphors in political discourse in croatian, american and italian newspapers. Academic Journal of Interdisciplinary Studies, 8(1), 69-76. https://doi.org/10.2478/ajis-2019-0007.

Sugiyono. (2013). Metode penelitian pendidikan pendekatan kuantitatif, kualitatif, dan r\&d. Alfabeta.

Surdyanto, A., \& Kurniawan, W. (2020). Developing critical reading module using integrated learning content and language approach. Studies in English Language and Education, 7(1), 154-169. https://doi.org/10.24815/siele.v7i1.15098. 